\title{
Presència i participació de treballadors i col-laboradors a les emissores de ràdio locals i comarcals de Catalunya
}

\author{
Sergi Solà Saña \\ Universitat de Vic \\ Josep Lluís Micó Sanz \\ Universitat Ramon Llull
}

\section{Palabras clave en castellano}

Comunicación local, radio, periodismo, trabajadores, colaboradores

\section{Resumen en castellano}

Uno de los factores que explica el funcionamiento de los medios de comunicación es la participación activa de personas en sus estructuras profesionales. En este sentido, los trabajadores y los colaboradores son piezas clave para que los medios puedan desarrollar su tarea social de ofrecer información a su audiencia. En un medio de comunicación concreto como son las emisoras de radio locales y comarcales de Catalunya, el factor humano tiene todavía una mayor incidencia para explicar su organización funcional y su oferta informativa. El presente artículo se centra en cuales son las tareas y responsabilidades que ejercen los trabajadores y colaboradores de las radios de proximidad catalanas. Se trata de las figuras profesionales que hacen posible el funcionamiento y la programación de estos medios, de forma que la vertiente humana de la comunicación es un elemento transversal. La investigación define las funciones de una y otra figura profesional, hecho que implica, entre otros aspectos, desglosar su relación con el medio. Los trabajadores y colaboradores ejercen tareas y asumen responsabilidades que pueden coincidir o que están diferenciadas, y que se vinculan con el puesto que ocupan dentro del organigrama de cada radio. Para conocer esta realidad se ha cruzado la metodología cuantitativa de la encuesta con la cualitativa de las entrevistas en profundidad. Para la investigación se han acotado los límites mediáticos y territoriales en las emisoras de radio de proximidad catalanas y se ha definido su situación laboral, centrándola en las figuras de los trabajadores y de los colaboradores. 


\title{
Presence and participation of workers and contributors in local and regio- nal radio stations in Catalonia
}

\section{Keywords}

Local communication, radio, journalism, workers, contributors

\begin{abstract}
One of the factors that explains the working of the media is the active participation of people in their professional structures. In this sense, employees and contributors are key for the media to develop their social task of providing information to their audience. In a specific media such as local and regional radio stations of Catalonia, the human factor still has a higher incidence to explain its functional organization and information supply. The paper tries to discover which are the tasks and responsibilities that the workers and contributors in Catalan radios take part in, and also the relations between them. These are the professional figures that make possible the operation and programming of the media, so that the human side of communication is a cross-cutting element of the investigation. The research defines the functions of the different professional figures, which implies, among others, the breakdown their relationship with the media. Workers and contributors exercise tasks and responsibilities that may coincide or that are differenced, and that are linked with the place they occupy in the organization chart structure of each radio. To know this situation it has been crossed the quantitative methodology of the survey with the qualitative research interviews. With the research have been confined media and territorial limits on local and regional radio stations in Catalonia and has defined the employment situation in the media, focusing on the figures of workers and collaborators.
\end{abstract}

\begin{abstract}
Autores
Josep Lluis Micó Sanz [JosepLluisMS@blanquerna.url.edu] es director del grado en Periodismo en la Facultat de Comunicació de Blanquerna, Universitat Ramon Llull.

Sergi Solà Saña [sergi.sola@uvic.cat] es profesor en la Universitat de Vic y en la Universitat Ramon Llull.
\end{abstract}




\section{Introducció}

El factor humà és un dels condicionants que expliquen el funcionament i la realitat dels mitjans de comunicació, perquè sense persones no es podrien elaborar i retransmetre notícies o no es podrien dirigir les organitzacions. Malgrat la creixent digitalització i tecnificació dels mitjans de comunicació (Pavlik, J.V.; Morgan, G.; Henderson, B., 2001), és per l'actuació de diferents figures professionals que es pot explicar la funció i la tasca social que porten a terme. I fer ràdio és, per a moltes persones, quelcom més que parlar per un micròfon, elaborar i emetre notícies i fer programes de temàtica variada (Paulussen, S.; Heinonen, A.; Domingo, D.; Quandt, T., 2007: 144). Per a molts dels participants de les emissores, fer ràdio és una activitat social que els permet expressar-se i fer arribar els seus coneixements i opinions a una audiència, formant part d'un mitjà de comunicació lligat a un municipi.

Així, els mitjans de comunicació ofereixen a la ciutadania un ventall informatiu ampli i permeten conèixer, a temps real, esdeveniments que tenen lloc tant a milers de quilometres com a pocs carrers de distància. I les diferents tipologies de mitjans existents es complementen per aportar al receptor una visió global d'una actualitat amb diferents cares (De Beer, A. S.; Merrill, J., 2004: 3-4).

De totes les variants que expliquen la realitat de les emissores de ràdio locals $\mathrm{i}$ comarcals de Catalunya, el present article se centra en el seu factor humà. Això significa que s'estudien les persones que les fan possibles, tant si hi treballen com si hi participen voluntàriament.

La figura del $\mathrm{col} \cdot$ laborador dels mitjans de comunicació és la gran oblidada del sector (Tomás Frutos, 2009: 94). La majoria de recerques acadèmiques sobre el tema se centren en els periodistes i professionals, obviant les persones que hi participen com a voluntaris, aportant el seu temps i els seus coneixements sense rebre, en la majoria dels casos, res a canvi.

Per tots aquests motius, la recerca se centra en la vessant humana i laboral d'un model concret de comunicació, les ràdios locals i comarcals de Catalunya. La investigació girarà sobre les figures dels professionals i dels col·laboradors, per conèixer-ne la seva incidència i aportació real en el funcionament dels mitjans. ${ }^{1}$

\section{Objectius}

L'objectiu de la investigació que es presenta és conèixer quines feines porten a terme els treballadors i $\mathrm{col} \cdot$ laboradors de les ràdios de proximitat catalanes, de manera que es pretén definir les funcions d'una i altra figura professional. Els treballadors i col-laboradors exerceixen tasques i assoleixen responsabilitats que poden coincidir o que estan diferenciades, i que es vinculen amb el lloc que ocupen dins l'organigrama del mitjà.

1 Aquest article s'ha fet en el marc de la tesi doctoral Els treballadors i els col laboradors de les emissores de ràdio locals i comarcals de Catalunya. Definició i funcions de les figures professionals. (Solà, 2012). 
Per tirar endavant la recerca, és imprescindible definir des d'un primer moment els objectius que es volen aconseguir i que guiaran en tot moment la investigació que es portarà a terme.

En primer lloc es vol determinar una tipologia de treballadors i col·laboradors per a les ràdios locals i comarcals de Catalunya, en funció de la relació laboral que tinguin amb l'emissora en què participen i que pot estar condicionada per factors com la formació o vàlua professional dels participants, però també per aspectes com les necessitats o possibilitats de les ràdios.

Per donar resposta a aquest plantejament inicial, el primer objectiu és definir les figures del treballador i del col laborador de les emissores locals i comarcals catalanes pel que fa a la seva relació contractual i temporal amb l'empresa i a la seva remuneració.

En segon lloc, interessa saber si hi ha una figura més nombrosa que l'altra i si el gruix principal de persones que treballen a les emissores són professionals o col·laboradors.

Ara bé, un fet és establir aquesta participació de forma numèrica i l'altre és veure quines responsabilitats assumeixen uns i altres. És per això que es veu necessari relacionar el nombre de treballadors i col laboradors que tenen les emissores amb el seu grau d'intervenció en la gestió i presa de decisions de les ràdios.

La intenció del segon objectiu és conèixer quants treballadors i col·laboradors hi ha a les ràdios locals i comarcals i quins llocs ocupen en la seva estructura. Per això es proposa saber quines responsabilitats assumeixen els treballadors i $\mathrm{col} \cdot$ laboradors a les emissores de proximitat catalanes, en funció del nombre en què hi participen i de les seves competències.

\section{Metodologia}

La recerca realitzada s'emmarca en la investigació en ciències socials, i per portar-la a terme s'han utilitzat diverses tècniques d'anàlisi i de recollida de dades, tant quantitatives com qualitatives, per tenir un coneixement detallat sobre l'objecte d'estudi.

\subsection{Mètode quantitatiu: l'enquesta}

La idea, definició i realització de l'enquesta s'ha fet segons els preceptes de Wimmer i Dominick (1996), que exposen que hi ha dos tipus d'enquestes: la descriptiva i l'analítica. La primera serveix com a reflex d'una situació actual, mentre que la segona pretén fer una descripció i explicar el perquè de determinades situacions. De les dues opcions, s'ha optat per la primera modalitat. Així, s'ha elaborat una enquesta basada en preguntes tancades, perquè interessa ob- 
tenir informacions concretes i quantitatives relacionades amb la situació laboral de les emissores de ràdio locals (Quivy, R.; Van Campenhoudt, L., 1997: 184).

Les dades obtingudes amb aquesta tècnica, però, no s'han pres com a única font d'informació per conèixer la realitat que s'estudia, sinó que s'han contrastat amb altres tècniques per aconseguir els objectius que es proposen, tal i com defensen Busquet, Medina i Sort (2006: 149), quan asseguren que utilitzar mètodes quantitatius permet crear uns indicadors a partir dels quals es poden descriure les característiques d'una realitat social, uns resultats que combinats amb altres metodologies conformen una visió global del tema estudiat.

La mostra que s'ha pres per realitzar les enquestes està formada per totes aquelles estacions amb seu social a Catalunya, que ofereixen la seva programació per a un territori delimitat territorialment, sigui un municipi o una comarca, i que no formen part de cap cadena d'un abast territorial més gran, ja sigui nacional o estatal.

Per seleccionar-la, s'ha pres com a base un estudi del Consell de l'Audiovisual de Catalunya $^{2}$ que referencia una llista segons la qual a Catalunya hi ha 258 emissores locals. Les dades s'han contraposat amb les de llistes publicades per l'Observatori de la Ràdio a Catalunya -segons la que hi ha 276 emissores $-^{3}$ i la Federació de Ràdios Locals de Catalunya -que en comptabilitza 237-. ${ }^{4}$

A partir d'aquest creuament d'informació s'ha obtingut una llista d'emissores locals i comarcals sobre la que s'ha treballat per enviar l'enquesta i que les ràdios participessin de la recerca que es porta a terme. Després de comprovar-ne el funcionament, s'ha enviat el qüestionari de la recerca a un total de 244 emissores de ràdio locals i comarcals de Catalunya.

Les ràdios participants han contestat l'enquesta, formada per 38 preguntes, a través d'Internet ${ }^{5}$ en el període de temps comprès entre el 15 de juny i el 18 de juliol de 2011. De les 244 enquestes enviades s'han rebut 126 respostes, que representen un $51,64 \%$ del total.

\subsection{Mètode qualitatiu: l'entrevista en profunditat}

La part qualitativa de la recerca s'ha fet a partir d'entrevistes en profunditat a treballadors i col·laboradors d'una mostra concreta d'emissores de ràdios locals.

\footnotetext{
2 Masip, P.; Micó, J. Ll. (2010b).

3 L'Observatori de la Ràdio a Catalunya recull al seu espai a Internet informació sobre la ràdio que es fa a Catalunya. Una de les seves eines és una llista de les emissores que es poden escoltar a cada comarca a través de la FM. Per confirmar la mostra de ràdios a estudiar i contrastar-la amb les dades del CAC, s'ha comprovat comarca a comarca aquelles emissores considerades com a municipals o locals. En aquest cas, s'ha obtingut una llista de 276 emissores de ràdio locals i comarcals: http://www.l-obsradio.cat [Consulta: 15 de març de 2011].

4 La Federació de Ràdios Locals de Catalunya, segons es recull al seu web, és una entitat que agrupa les emissores locals de titularitat pública i els ofereix assessorament tècnic i jurídic, a més de formació i subministrament de programació. La llista de ràdios associades a la Federació, un total de 237, també s'ha pres com a base de la recerca per elaborar la mostra de ràdios a estudiar: http://www.radiolocal.cat. [Consulta: 15 de març de 2011].

5 La gestió per Internet de les enquestes i la recollida de les respostes i de les dades obtingudes s'ha fet a través de la pàgina web http://www.encuestafacil.com.
} 
Igual que passava quan es definia el tipus d'enquesta a realitzar, a l'hora de decantar-se per un model d'entrevista, s'ha pres com a base l'obra de Wimmer i Dominick (1996: 132), que en diferencien dos tipus, l'estructurada i la inestructurada: «En la entrevista estructurada las preguntas previamente fijadas se plantean en el orden preestablecido, con escasa libertad de acción para los entrevistadores. En la entrevista inestructurada se plantean en cambio preguntas de sentido más general, lo que implica para los entrevistadores mayor intervención propia a la hora de añadir repreguntas que sirvan para obtener la información deseada.» De les dues modalitats d'entrevistes en profunditat proposades per Wimmer i Dominick, s'ha optat per la realització d'entrevistes estructurades perquè és la modalitat més directa amb la que es pot aconseguir un coneixement ampli de la realitat laboral de les emissores de ràdio locals i comarcals, aprofundint en les dades que s'hagin obtingut de les enquestes (Taylor, S.J.; Bogdan, R., 1992: 101).

A l'hora de definir la mostra d'emissores on fer les entrevistes, s'ha escollit un total de 12 ràdios de les 126 que han participat a la part quantitativa de la investigació. ${ }^{6}$ Per fer la selecció, s'ha pres com a punt de partida una sèrie de condicionants que determinen el conjunt de ràdios que configuren la part qualitativa de la recerca, i se n'han creuat les dades per obtenir la mostra representativa: la representació territorial, l'antiguitat, la titularitat, la cobertura i la infraestructura laboral. Després de fer el creuament, s'ha arribat a una llista de 12 emissores de ràdio on s'han portat a terme les entrevistes: Cerdanyola Ràdio; Cugat Ràdio; Ràdio Silenci; Ràdio Taller Trinitat Vella; Ràdio L’Escala; Bas Ràdio; Ràdio Manlleu; Ràdio Santpedor; Constantí Ràdio; Ràdio Les Borges; Ràdio Delta; RàdioSeu.

De cada emissora de la mostra s'han seleccionat tres persones a entrevistar en funció de la seva condició laboral. Així, s'ha parlat amb els directors o responsables de totes les ràdios, amb un treballador, i amb un col·laborador de cada una d'elles. En total, en aquesta vessant qualitativa de la investigació s'han realitzat 32 entrevistes en profunditat, que han tingut lloc als estudis de les diferents emissores de ràdio.

\section{Les figures professionals als mitjans de comunicació locals}

Les figures professionals dels mitjans de comunicació i, més concretament, de les emissores de ràdio locals i comarcals, són al centre d'aquesta investigació. D'entre aquestes figures, es vol fer una distinció entre les que hi treballen de forma professional, rebent una compensació econòmica per la seva feina, les que hi col·laboren de forma continuada rebent una remuneració econòmica, i les que ho fan de manera desinteressada i voluntària.

\footnotetext{
6 No existeix un barem exacte sobre el nombre d'entrevistes que cal realitzar per a una recerca com la que s'afronta. Malgrat això, el més habitual per una mostra com la que es tracta, són les investigacions que oscil len entre la desena i la quinzena d'entrevistes. Un exemple és una recerca de García Avilés (2007). També es pot prendre com a referència l'elecció de la mostra que es va fer per a un estudi del Grup de Recerca en Interaccions Digitals de la Universitat de Vic: Scolari, C. A.; Navarro Güere, H.; Pardo Kuklinski, H.; Micó, J. Ll. (2008). I encara, una investigació del grup de recerca Digilab, de la Universitat Ramon Llull, guanyadora del premi de recerca que organitza l’Associació Catalana de Premsa Comarcal: Masip, P.; Micó, J. Ll. (2010a).
} 
En primer lloc, cal discernir entre la figura del treballador professional i del col-laborador. Però per fer-ho, s'ha de distingir què és cada una d'aquestes figures. Què s'entén per professional de la ràdio i per col·laborador. I dins dels col·laboradors, saber quins d'ells treballen a canvi d'una remuneració econòmica i quins ho fan de forma altruista o voluntària.

\title{
4.1. Concepte de treballador
}

Dins la diversitat de figures professionals que fan possibles els mitjans de comunicació, els treballadors són els que fan la seva feina a canvi d'una remuneració econòmica i estan vinculats a l'empresa per una relació contractual.

Segons el Diccionario de Comunicación Corporativa e Institucional y Relaciones Públicas (2004: 140), un professional és aquella «persona especializada o técnica que desarrolla su actividad de trabajo dentro de una organización». Es veu, per tant, que és imprescindible que el professional tingui una relació laboral amb una empresa i que la feina sigui especialitzada.

Als mitjans de comunicació, i concretament a les emissores de ràdio, les feines que es porten a terme són especialitzades, ja siguin des de l'apartat tècnic com des de la realització de continguts i l'emissió. En aquest darrer cas, els professionals que hi treballen són periodistes o persones que han realitzat estudis de Comunicació.

Per definir millor la figura del periodista, i centrant-la en la realitat de Catalunya, la referència seria l'Estatut del periodista professional del Col·legi de Periodistes de Catalunya (2000: 3):

\begin{abstract}
«Es considera com a tal tot aquell que té per ocupació principal i remunerada l'obtenció, elaboració, tractament i difusió per qualsevol mitjà d'informació d'actualitat, en format literari, gràfic, audiovisual o multimèdia, amb independència del tipus de relació contractual que pugui mantenir amb una o diverses empreses, institucions o associacions.»
\end{abstract}

No totes les persones que treballen als mitjans com a professionals, però, han rebut la formació considerada necessària a priori. Per tant, es fa necessària la definició de l'exercici professional als mitjans de comunicació des d'una dimensió objectiva, que només es pot assegurar gràcies a l'acreditació mitjançant un títol oficial (Scholl, 1996: 335).

\subsubsection{La professió periodística}

L'estudi sobre el periodisme ha versat en qüestions relacionades amb els mitjans de comunicació i la feina que porten a terme els professionals de la matèria, però s'han oblidat, en molts casos de les persones que la desenvolupen. En aquest sentit, Mosco (2008) destaca:

«Research in communication studies has tended to cluster around the exploration of three interconnected topics: media, messages, and audiences. (...) The field has produced rich and 
varied work, but one aspect has received little attention: labor. Intellectual and physical labor are required to produce messages and the technologies used to disseminate them.»

Encara en l'explicació del que és el periodisme, Deuze (1999) creu que una definició àmplia del terme hauria d'incloure «a wider definition would include a horizontal view on journalism, looking at the range of different genres, niches and specialisation's contemporary journalists work for.» De fet, hi ha més autors que defensen aquest canvi de tendència en el que és el periodisme, i n'hi ha, com Bardoel (1998) que expliquen: «Journalism in general is defined here as the professional selection of actual news facts to an audience by means of technological distribution methods». Es pot considerar l'ofici de periodista com una feina de coneixement, perquè consisteix en captar informacions, processarles i fer-les arribar a una audiència. En aquest sentit, la professió periodística està situada al costat d'altres feines que tenen finalitats similars, i que descriuen Mosco, McKercher i Huws (2010: 3):

«Farther along the spectrum we find a more expansive definition of knowledge work, on that includes the labor of those who handle, distribute, and convey information and knowledge. These are, in a manner of speaking, message takers and message movers, rather than message makers. This definition applies to teachers, journalists and librarians at the more knowledge-intense end of the category, and media technicians and postal workers at the other end.»

Segons aquests autors, els treballadors del coneixement coincideixen en fer de la informació el seu producte, a partir de qualsevol tecnologia, i ho poden fer des d'una vessant tècnica i material o intel·lectual i cognitiva. Seguint aquesta definició, es pot considerar els periodistes com a treballadors del coneixement. ${ }^{7}$

\subsubsection{La realitat laboral als mitjans de comunicació de Catalunya}

Si se centra la mirada en la situació actual dels mitjans de comunicació de proximitat a Catalunya s'ha de fer referència al concepte de convergència comunicativa. I aquí, es pot prendre com a referència l'obra de Masip i Micó (2010a: 67), que han encapçalat la recerca feta en aquesta matèria fins al moment. Els autors destaquen que la convergència als mitjans locals i comarcals «és possible gràcies a la digitalització i també al progressiu procés de concentració empresarial i diversificació multimèdia». Aquesta convergència es resumeix en mitjans que, a partir una mateixa redacció, creen continguts que es poden oferir a través de la premsa, la ràdio, la televisió, o Internet. De fet, la xarxa ha provocat canvis significatius en la forma de treballar dels periodistes (Doménech, 2011: 233-235).

Per aquest motiu, els professionals que treballen en aquests mitjans han de dominar la redacció per als diferents formats, i en moltes ocasions han de ser capaços de redactar una mateixa informació per al diari, en paper o digital, per a un butlletí informatiu radiofònic o per a un noticiari televisiu (Stevens, 2002).

7 McKercher i Mosco aprofundeixen en la definició de treballadors del coneixement a la seva obra Knowledge workers
in the information society, on fan una compilació de la situació internacional d'aquests treballadors de la societat del coneixement. Per conèixer el detall de la recerca, vegeu: McKercher, C.; Mosco, V. (2007). 


\subsubsection{La situació a la ràdio}

El mitjà de comunicació sobre el que se centra aquesta investigació, la ràdio, ha anat consolidant amb els pas dels anys unes figures professionals que desenvolupaven les seves activitats per permetre el funcionament de les emissores. La introducció de les noves tecnologies digitals de comunicació en els darrers anys, però, han portat a un canvi en aquests perfils professionals de les ràdios. López i Ortiz (2011) expliquen que, tradicionalment, les ràdios d'Espanya han tingut diversos perfils professionals, com locutors, guionistes i redactors o tècnics de so, entre d'altres. Malgrat això, expliquen:

«Con la implementación tecnológica derivada de la digitalización de todos los procesos, las emisoras de radio han liberado franjas horarias de emisión, han facilitado muchas tareas a redactores, locutores y guionistas y han hecho posible la difusión de información con más calidad de sonido.»

Per aquests motius, el concepte que defineix millor la situació de les figures professionals a la ràdio actual és el de polivalència, perquè, gràcies a les noves tecnologies, una mateixa persona pot fer diferents feines.

\subsection{Concepte de $\mathrm{col} \cdot$ laborador}

Per tenir una primera aproximació del que és un col·laborador, es pren com a base la definició que el Diccionario de Comunicación Corporativa e Institucional y Relaciones Públicas (2004: 41) fa de la col·laboració professional: «Trabajo que se realiza de mutuo acuerdo entre un profesional y la organización que lo admite, cuando se considera oportuno por ambas partes».

Per la seva banda, al Diccionari bàsic de la Comunicació (2002: 33) es defineix la col-laboració com el «treball, desinteressat o no, d'una persona per a un mitjà informatiu», i el col·laborador com la "persona que escriu en un mitjà però no pertany pròpiament a la plantilla». Per tant, a diferència del professional, el col·laborador no té cap lligam contractual amb l'empresa.

També es pot prendre com a referència un estudi de Benlloch (2007), que situa la diferència entre el treballador professional i el voluntari en el fet que «la existencia o no de contraprestación económica se erige en el criterio fundamental de distinción entre ambas relaciones jurídicas, visto que entre los caracteres esenciales del voluntariado se encuentra la gratuidad y el altruismo, objetivado en la ausencia de la contraprestación». Per la seva banda, Petrus (1991: 24) defineix el voluntari com la persona que «actua lliurement, habitualment ho fa associat amb altres; aporta el seu treball; sense compensació econòmica; de forma altruista». En tots dos casos, el que caracteritza el treball del voluntari o col·laborador és que, per norma general, no percep cap compensació econòmica per la seva feina.

Segons aquestes definicions, els col-laboradors no formen part de les estructures professionals dels mitjans, de manera que no tenen la mateixa situació legal que els treballadors. Aquesta realitat es tradueix en precarietat laboral, com defineixen 
Cantalapiedra, Coca i Bezunartea (2000) quan expliquen que la majoria dels casos de precarietat als mitjans són de col·laboradors, que «pueden disfrutar de ese estatus el tiempo que quieran, sin apenas esperanzas de que la empresa decida incorporarlos a la nómina, ni tampoco mucho miedo de que prescinda de sus servicios».

\subsubsection{La situació a la ràdio}

Sobre la participació de col-laboradors i voluntaris a les emissores de ràdio locals, amb el seu pes comunitari, Lewis i Booth (1989: 9) expliquen que «the presence of volunteers is not the result of cost-saving calculations but is an essential means of contact with the community or communities involved, ensuring that they are represented in the day-to-day running of the station».

Per la seva banda, al Llibre blanc de la ràdio local pública (Federació de Ràdios Locals de Catalunya, 2008), s'hi explica que una de les claus de l'èxit que ha tingut la ràdio local a Catalunya s'ha de buscar en què, des dels seus inicis, s'ha sabut identificar l'oient a qui es dirigia la comunicació i el propi mercat, que és el de la proximitat, i en què la ràdio local catalana té una característica que la fa singular, i és l'elevat nombre de persones que hi col-laboren (Federació de Ràdios Locals de Catalunya, 2008: 28):

«Aquest fenomen del voluntariat, de la persona $\mathrm{col} \cdot$ laboradora que treballa de manera altruista, no genera una conflictivitat mínimament destacable sinó que es tracta d'una fórmula que desperta interès, perquè la ràdio local és un espai que pot motivar la participació ciutadana i un lloc d'aprenentatge i de formació per a estudiants, i d'expressió per a persones apassionades pel món de la ràdio.»

Els voluntaris són clau per a moltes emissores de proximitat, no només a Catalunya sinó també a escala internacional, i realitzen moltes de les tasques possibles per al funcionament dels mitjans. Tal i com descriuen Price-Davies i Tacchi (2001: 66):

«Volunteers perform a wide range of roles in community stations -including administration, technical support, production, and presentation. They are supported in these activities by the stations themselves, who usually provide training workshops, and by the representative organisations in each of the countries, which often organise development activities, and help to foster networking between stations.»

I és que malgrat les diferències de funcionament de les emissores que hi pugui haver en els diferents països, el que no canvia és el fet que els voluntaris de les ràdios hi poden jugar un paper fonamental i portar a terme qualsevol de les tasques necessàries per al seu funcionament (Tievant, S.; Chaguiboff, J., 1986: 136).

\subsection{Marc legal}

La figura del treballador professional està emparada per la legalitat que li confereixen els contractes laborals i l'Estatut dels treballadors. ${ }^{8}$ La situació del

8 Alguns autors defensen la necessitat de l'aprovació d'un Estatut Professional per al periodisme, per concretar l'activitat que es realitza al sector i perquè el periodisme es consideri una professió i no una ocupació. Vegeu: Real, E. (2006: 333-361). Per la seva banda, Escobar considera: «En España el estatuto de los periodistas, entendido como el 
col·laborador, en canvi, no està tan clara, i pot variar en funció del mitjà en què es treballi i de la relació que es pugui establir segons la feina que es porta a terme.

Abans d'entrar en l'estudi de la vinculació legal dels col·laboradors amb els mitjans de comunicació, a partir dels convenis col·lectius i de la jurisprudència, es considera d'interès veure quines opcions existeixen per a la contractació de professionals.

Per fer-ho es pren de base el capítol de Francesc Casares «Dret laboral i seguretat social: Règim jurídic del treball professional del periodista», recollit a la Guia jurídica del periodista editada pel Col-legi de Periodistes de Catalunya. Al seu treball, Casares (1991: 105-108) exposa que existeixen tres models de relació possibles entre periodistes i mitjans. El primer és una relació «purament civil», el segon model es basa en una relació «administrativa», i en tercer lloc, es pot establir una relació «típicament 'laboral'».

Pel que fa al marc legal pròpiament dit, és a dir, a les normes jurídiques que recullen les relacions professionals entre treballadors i mitjans de comunicació, existeixen tres normes generals. Així ho exposa Casares (1991: 110):

«a) En primer lloc, cal mencionar la Constitució Espanyola. Són diversos els articles de la CE que, directament o indirecta, afecten els drets dels treballadors i, entre ells, alguns dels que la Constitució enumera com a drets fonamentals de la persona. Aquests drets són directament exigibles per tothom, atès el que s'anomena caràcter normatiu de la Constitució, i els Tribunals els han d'aplicar.

b) En segon lloc, l'Estatut dels Treballadors. Aquest és un text fonamental; és el marc legal bàsic de tota relació laboral.

c) En tercer lloc, hi ha un conjunt de normes legals promulgades com a Lleis, Decrets o simples Ordres Ministerials que regulen problemes específics o concrets de la relació laboral, però aplicables a totes les empreses i a tots els treballadors, qualsevol que sigui el tipus de treball de què es tracti.»

\section{Les figures professionals a les ràdios locals i comarcals catalanes}

Les emissores de ràdio locals i comarcals de Catalunya són uns mitjans de comunicació que per poder funcionar necessiten de la participació de diverses figures professionals. És gràcies a la unió de la feina de diferents persones en departaments interrelacionats entre sí que les ràdios locals, igual que els altres mitjans de comunicació, poden oferir la seva producció a l’audiència.

Així, en el present article es para atenció als equips humans que conformen el cos laboral de les emissores de ràdio de proximitat. Les persones són essencials per al funcionament de les ràdios locals, i hi poden prendre part en dues modalitats: com a professionals en plantilla o com a col·laboradors, i es vol veure quines figures conformen les plantilles laborals de les ràdios locals catalanes, estudiant per separat els treballadors contractats i els col·laboradors.

conjunto de derechos y deberes propios de esta profesión, tanto en su faceta individual como colectiva, se encuentra actualmente disperso en normas de naturaleza heterogénea y variado contenido.» Vegeu: Escobar Roca, G. (2002: 64). 


\subsection{El cos de treballadors de les emissores}

El funcionament de les ràdio locals, així com de qualsevol mitjà de comunicació, no seria possible sense la presència activa de persones fent totes les tasques necessàries perquè tirin endavant. En el cas dels treballadors, es fa referència a les persones que tenen contracte laboral amb l'empresa, amb la intenció de conèixer-ne la tipologia a partir d'aspectes com els seus estudis o la seva dedicació, exclusiva o no, a l'emissora.

La presència de treballadors es dóna a la majoria d'emissores de ràdio locals i comarcals catalanes, concretament, en un $78 \%$. Aquesta xifra és important perquè demostra que, en la part contrària, un $22 \%$ de les emissores funcionen sense que hi participi cap persona contractada (veure Figura 1).

Figura 1. Participació de treballadors i col $\cdot$ laboradors a les emissores

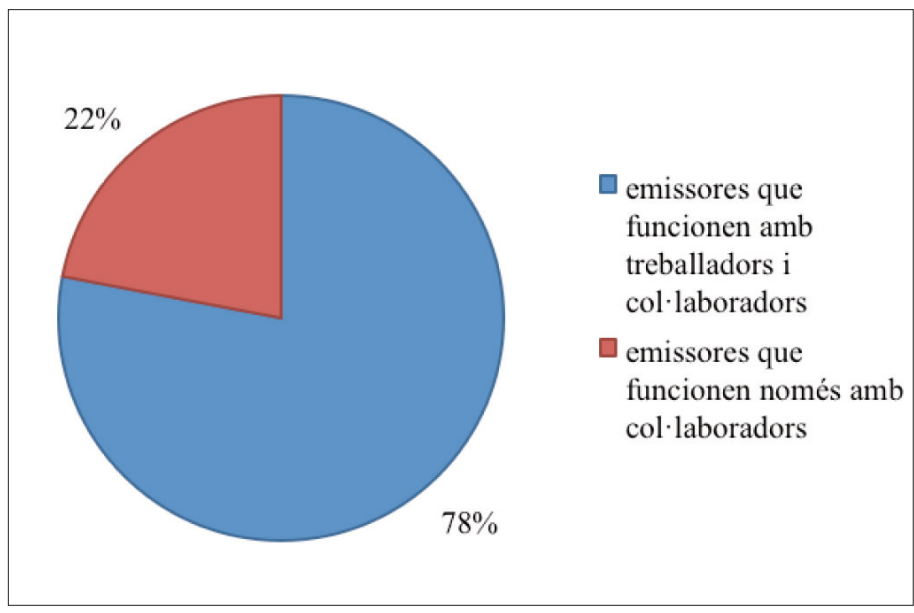

Font: elaboració pròpia

Pel que fa al nombre de treballadors contractats per les ràdios locals i comarcals, es pot observar una varietat de xifres, des de les emissores que només hi tenen una persona fins les que en tenen fins a 36. (veure Figura 2).

\subsubsection{Nivell formatiu i experiència dels treballadors}

Els treballadors de les emissores es poden dividir en dues categories: els directors i els professionals en plantilla. Aquesta divisió es fa perquè la majoria dels directius cobren per fer la seva feina, fet que es dóna en totes les ràdios en què hi ha algun treballador contractat. Els directors que no cobren per la seva feina ho són de les emissores en què no hi ha cap treballador en plantilla. 
Figura 2. Treballadors a les ràdios locals (en percentatges)

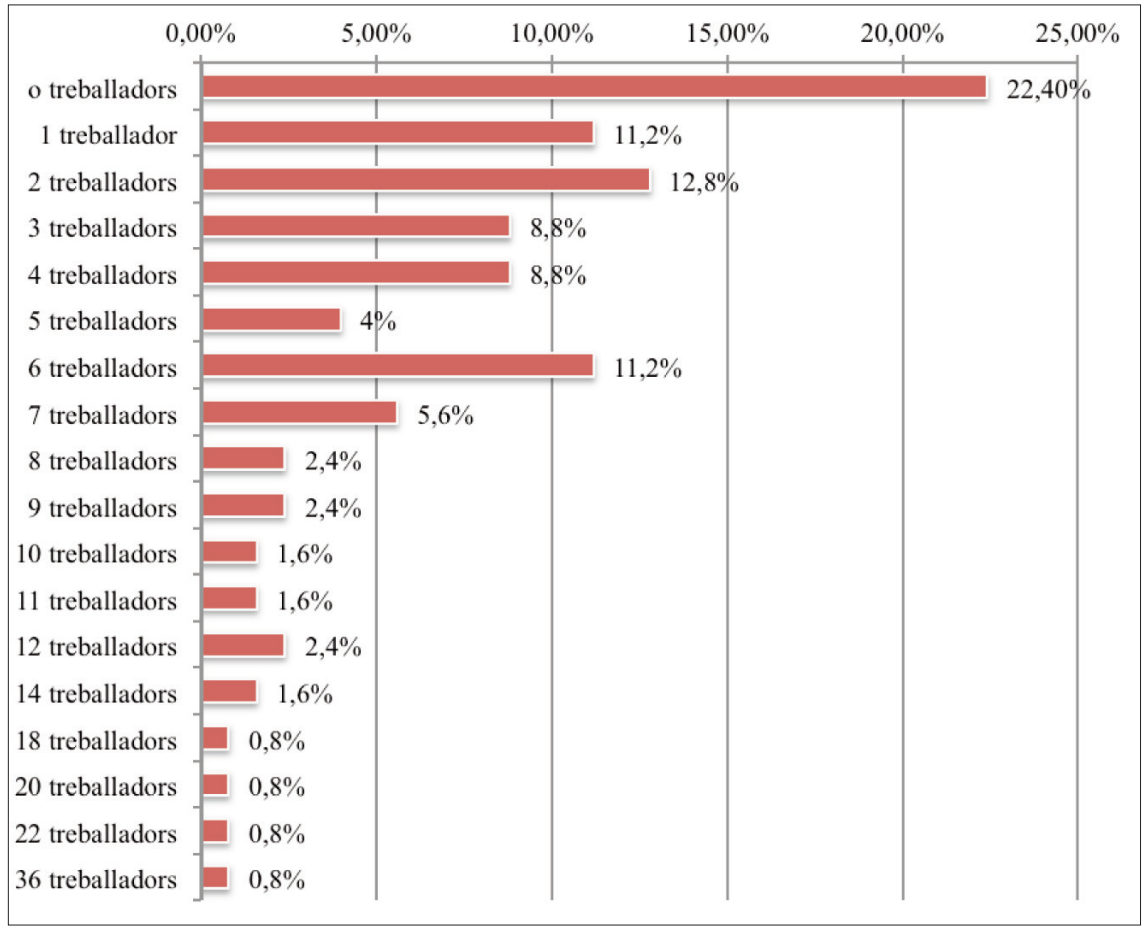

Font: elaboració pròpia

La majoria de persones que formen els equips directius de les ràdios tenen estudis universitaris, encara que no totes. De les que no han cursat estudis a la universitat, n'hi ha que ho estan fent actualment, que van estudiar fins la Selectivitat, o que tenen un mòdul de grau superior posterior a la Formació Professional. Pel que fa a les persones amb estudis universitaris, no totes han cursat carreres relacionades amb la Comunicació. Si bé hi ha llicenciats en Periodisme, Comunciació Audiovisual o Ciències de la Informació, a la direcció també hi ha llicenciats en Dret o en Història.

Un fet que ha permès conèixer la recerca ha estat el temps que els directors porten vinculats amb les emissores on treballen. Excepte tres casos, en què el primer contacte entre els responsables i el mitjà es va produir fa menys de cinc anys -a Ràdio Manlleu el 2007, a Ràdio Silenci el 2008 i a Ràdio Taller Trinitat Vella el 2009-, la resta de directors van entrar en contacte amb les emissores fa més de 10 anys -a Bas Ràdio el 1995, a RàdioSeu el 1991, a Ràdio Les Borges el 1996, a Constantí Ràdio el 1999, a Ràdio Delta el 1986, a Cerdanyola Ràdio el 1989, a Ràdio L'Escala i el 1994 i a Cugat Ràdio el 1996-. 
En tots els casos, els directors van fer altres feines a la ràdio abans d'accedir al seu càrrec actual.

En el cas dels professionals en plantilla, la seva formació depèn de la feina que fan a les ràdios. Així, es troben persones amb estudis universitaris acabats o a punt de finalitzar. En aquest cas, la majoria han cursat i cursen carreres relacionades amb la Comunicació -Periodisme o Comunicació Audiovisual- però també hi ha carreres com Filologia Catalana. Les persones que treballen a les ràdios però que no han cursat estudis universitaris han estudiat Formació Professional.

\subsubsection{Estabilitat professional dels treballadors}

Més enllà dels estudis cursats pels treballadors, un dels elements que ajuden a conèixer la situació laboral dels mitjans de comunicació és la seva estabilitat professional. És a dir, si aquestes persones treballen exclusivament per a un sol mitjà o si ho fan per més d'una empresa, i són més les ràdios en què els seus treballadors no treballen exclusivament a l'emissora que aquelles en què els professionals només exerceixen allí. En xifres, en un $48 \%$ de les ràdio locals i comarcals catalanes els treballadors amb contracte s'hi dediquen exclusivament, de manera que en el $52 \%$ d'emissores restant els seus treballadors combinen la feina a la ràdio amb altres ocupacions (veure Figura 3 ).

Figura 3. Dedicació exclusiva dels treballadors a les emissores

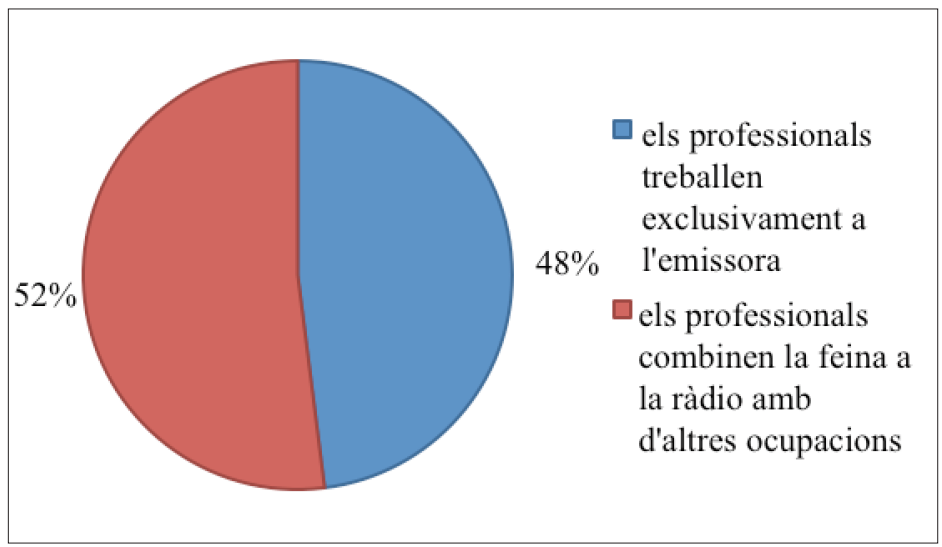

Font: elaboració pròpia

De les dades recollides se'n pot extreure que el sector de les ràdios locals i comarcals catalanes no ofereix unes condicions laborals i econòmiques prou adequades com perquè els seus professionals s'hi dediquin exclusivament. Aquestes perso- 
nes, per tant, dediquen part del seu temps laboral a treballar en una ràdio local i la resta a d'altres ocupacions, que poden estar, o no, lligades amb el món de la comunicació. Així, en un $52 \%$ dels casos, les persones que treballen a les ràdios ho fan també en altres mitjans de comunicació, i en un 48\% combinen la feina a l'emissora amb una altra tasca fora de l'àmbit comunicatiu (veure Figura 4).

\section{Figura 4. Ocupació dels treballadors fora de les emissores}

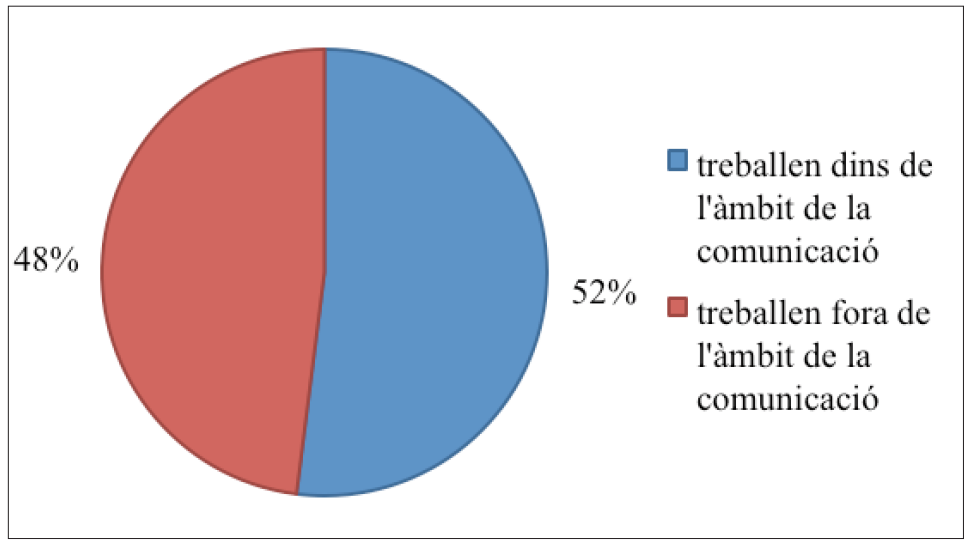

Font: elaboració pròpia

L'anàlisi d'aquestes dades mostra que la majoria dels treballadors de les ràdios locals estan vinculats professionalment al món de la comunicació, ja sigui únicament a les emissores o conjuntant la feina a les ràdios amb altres mitjans. Per bé que més de la meitat dels treballadors han de combinar l'ocupació a les ràdios amb altres feines, són més les persones que continuen lligades a l'àmbit de la comunicació, en altres mitjans, que les que han de sumar la feina de la ràdio amb activitats fora del món comunicatiu.

\subsection{El cos de col·laboradors de les emissores}

Segons s'ha comprovat, a les emissores de ràdio locals catalanes hi ha treballadors en plantilla i col·laboradors, que poden cobrar o no per la seva feina. Una de les dades recollides per la investigació demostra que no totes les ràdios tenen professionals, però sí que totes elles tenen col·laboradors, en major o menor nombre (veure Figura 5). 
Figura 5. Col · laboradors a les ràdios locals (en percentatges)

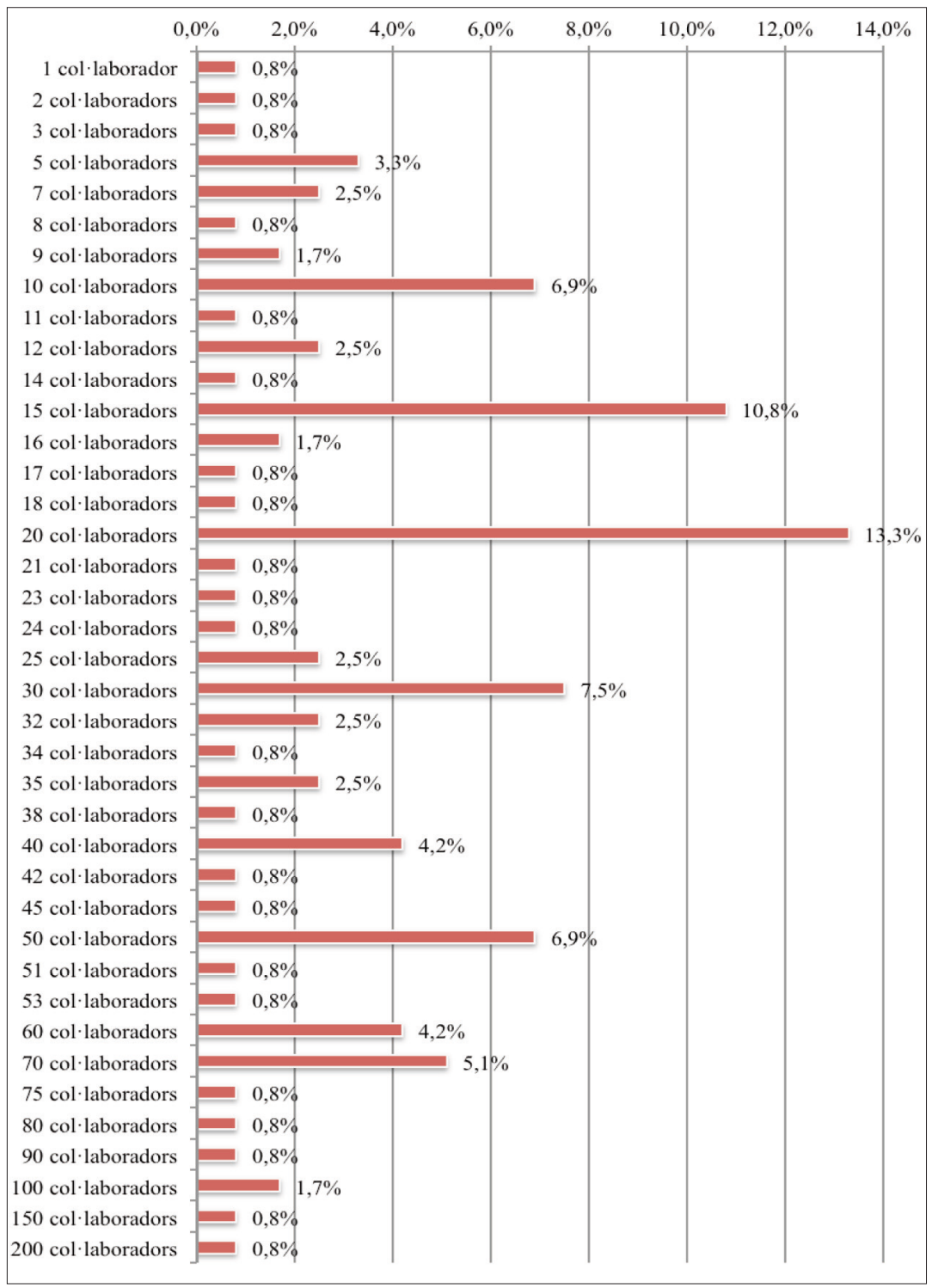

Font: elaboració pròpia 


\subsubsection{Remuneració dels col·laboradors}

El que interessa en aquest punt és veure quants col·laboradors reben una remuneració econòmica per formar part de les ràdios, encara que sigui més baixa que la que perceben els professionals, i quants no ho fan. Vist el global dels resultats obtinguts a la recerca, els $\mathrm{col} \cdot$ laboradors que cobren són una minoria davant dels voluntaris, perquè hi ha un $25 \%$ de col·laboradors que cobra i un $75 \%$ que no ho fa (veure Figura 6 ).

Figura 6. Remuneració dels col·laboradors

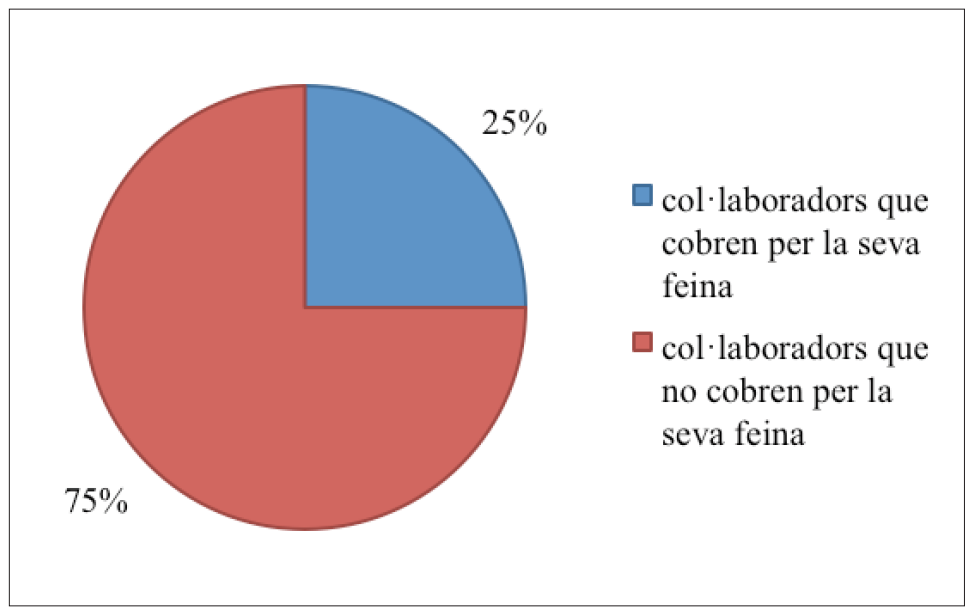

Font: elaboració pròpia

Per dibuixar millor el perfil dels col · laboradors i la seva distribució pel mapa radiofònic local català, es pot mirar com es reparteixen en nombre i percentatges, separant en dues realitats els col·laboradors que cobren dels que no ho fan. En primer lloc, es pot veure que les ràdios que tenen $\mathrm{col} \cdot$ laboradors remunerats ho fan en un nombre que va entre una i 15 d'aquestes persones (veure Figura 7). 
Figura 7. Col · laboradors remunerats (en percentatges)

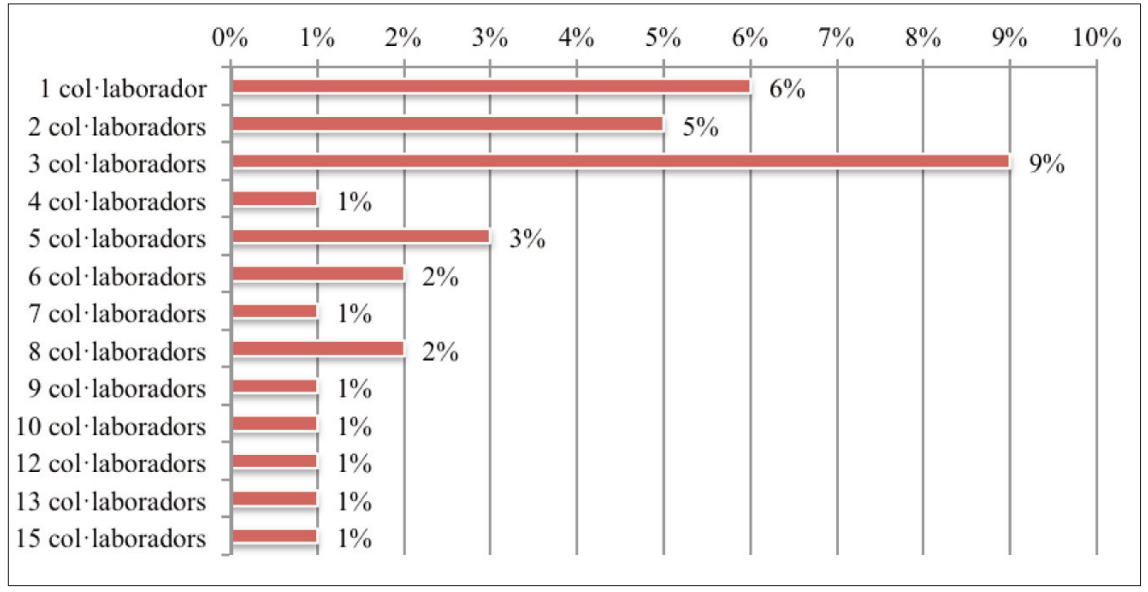

Font: elaboració pròpia

En el cas de les emissores que tenen col·laboradors no remunerats, és a dir, voluntaris, les xifres són més altes. Així s'explica que només hi hagi una emissora amb un col laborador no remunerat i que les ràdios amb un nombre més elevat en tinguin més de 151 (veure Figura 8).

Comparant les xifres de col-laboradors remunerats i no remunerats, doncs, s'observa que hi ha més ràdios que tenen col·laboradors voluntaris que col·laboradors cobrant i els tenen en major nombre.

\subsubsection{Nivell formatiu i experiència dels $\mathrm{col} \cdot$ laboradors}

En el cas del nivell formatiu dels col-laboradors, es pot trobar una gran diversitat d'opcions, com diverses són les persones que col·laboren en un mitjà de comunicació. Així, es poden distingir de forma clara dos nivells de col·laboradors en quant a la seva formació. D'una banda, hi ha les persones que participen de les ràdios com una activitat de lleure i les persones que estan interessades en el món de la comunicació, des d'un punt de vista professional, i que participen d'aquestes ràdios com una via per obrir-se camí en el món dels mitjans.

Una altra dada significativa està relacioanda amb l'experiència prèvia en emissores de ràdio locals i és que, excepte en dos casos, tots els col·laboradors han entrat en contacte amb aquest sector a través de la ràdio en què participen en l'actualitat. Si es mira el temps que fa que col-laboren a la seva emissora, s'observa una diversitat de respostes que coincideixen amb el perfil de $\mathrm{col} \cdot \mathrm{lab}$ oradors vist fins ara. Així, els estudiants de Periodisme o recent llicenciats porten poc temps de contacte amb la ràdio, mentre que la resta de persones 
l'han mantingut al llarg dels anys, i en alguns casos es manté des de l'inici de l'activitat de l'emissora.

Figura 8. Col · laboradors no remunerats (en percentatges)

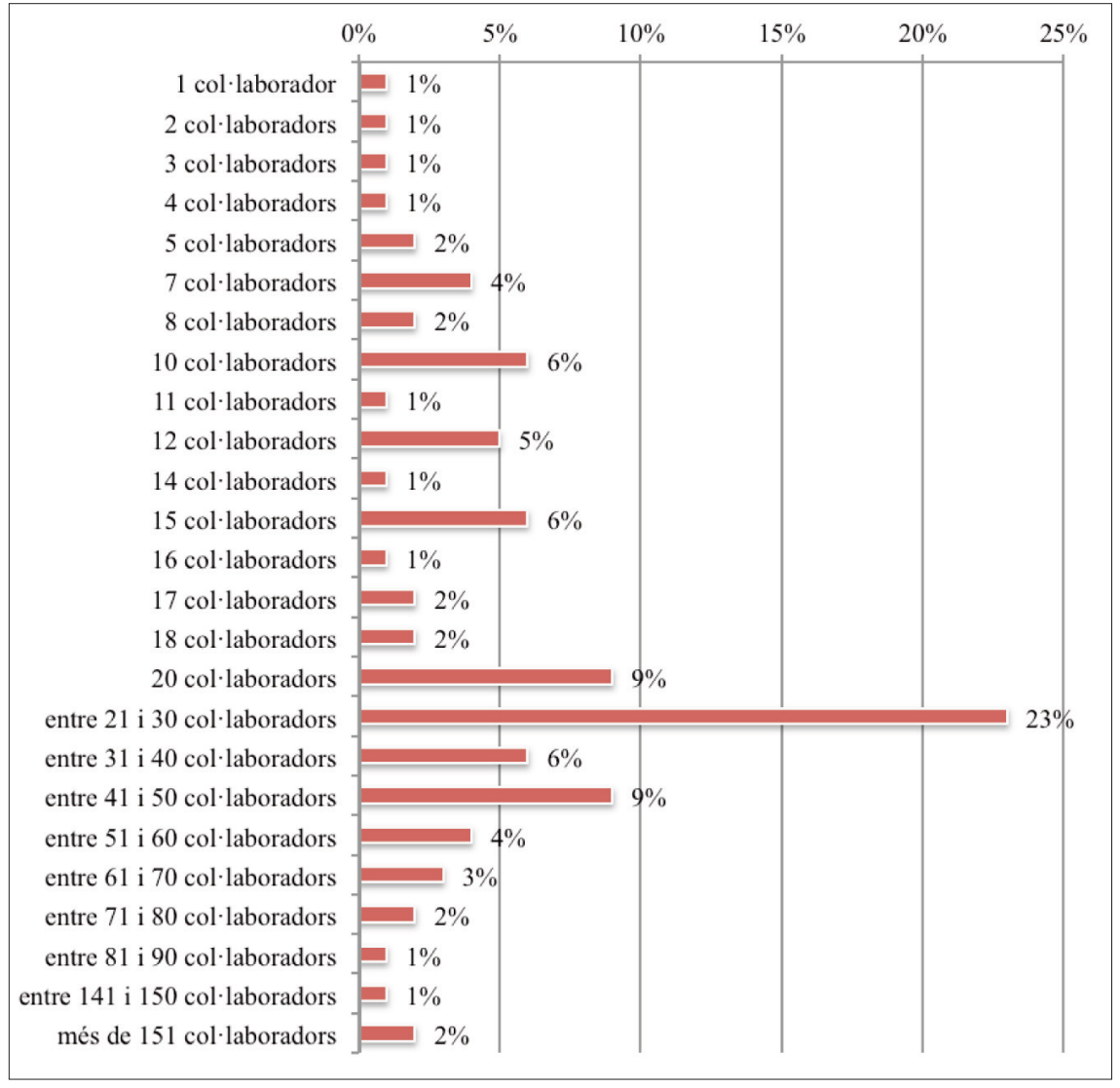

Font: elaboració pròpia

\subsubsection{Formació rebuda per part de l'emissora}

Una de les funcions que poden realitzar les emissores locals és la d'escola de ràdio. I ho poden fer oferint formació a les persones que s'hi incorporen, especialment als $\mathrm{col} \cdot$ laboradors. Però també perquè són un espai d'aprenentatge per als professionals, on aprenen els mecanismes i les rutines de treball que després poden aplicar en altres moments de la seva vida professional. En aquest 
sentit, la presència d'estudiants universitaris o de persones recent llicenciades a les ràdios, ja sigui com a professionals o $\mathrm{col}$ - laboradors, corrobora el fet que la ràdio local és un lloc d'aprenentatge per als futurs periodistes.

Per tal d'estudiar la formació que les ràdios ofereixen a les seves figures professionals, s'ha de partir dels resultats de la recerca realitzada per a la investigació. En aquest sentit, es prenen com a base els resultats de l'enquesta i ens centrem en la figura dels $\mathrm{col} \cdot$ laboradors, i es veu que la majoria de ràdios ofereixen una formació a aquestes persones; concretament, ho fa un $64 \%$ del total. Aquest resultat indica, doncs, que hi ha un $36 \%$ de ràdios locals i comarcals de Catalunya que reconeixen no oferir cap mena de formació als seus col·laboradors (veure Figura 9).

Figura 9. Formació oferta per les emissores als col·laboradors

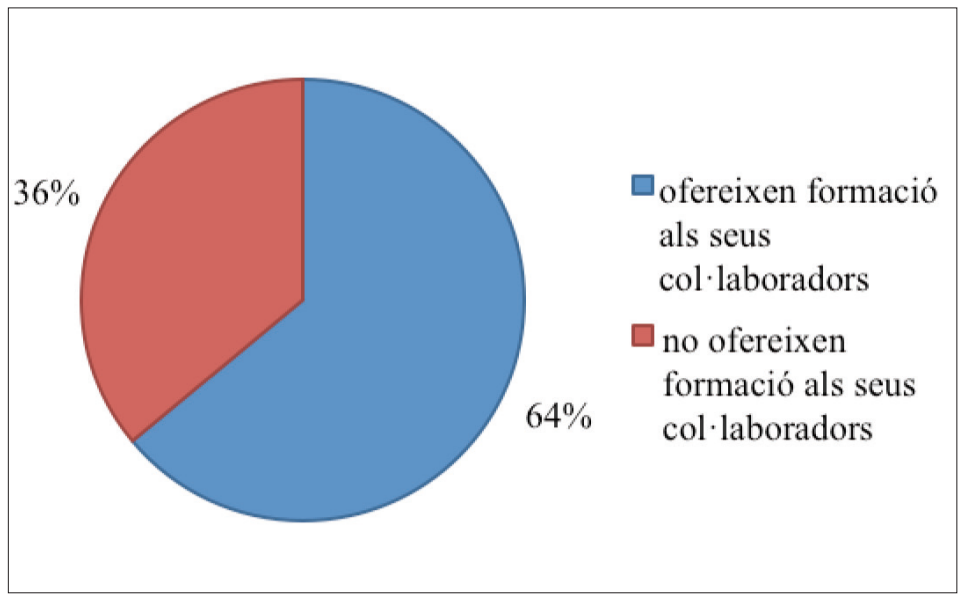

Font: elaboració pròpia

Una dada que cal tenir en compte, però, és el moment en què es forma als $\mathrm{col}$-laboradors que s'integren a les emissores de ràdio: Les emissores que formen als col·laboradors només quan comencen són el $46 \%$ del total, i les que mantenen aquesta formació al llarg de l'estada dels col·laboradors són el 54\% restant (veure Figura 10).

Es veu, per tant, que la majoria de ràdios formen als seus col·laboradors i que, dins de les que ofereixen la formació, més de la meitat la mantenen al llarg del temps. 


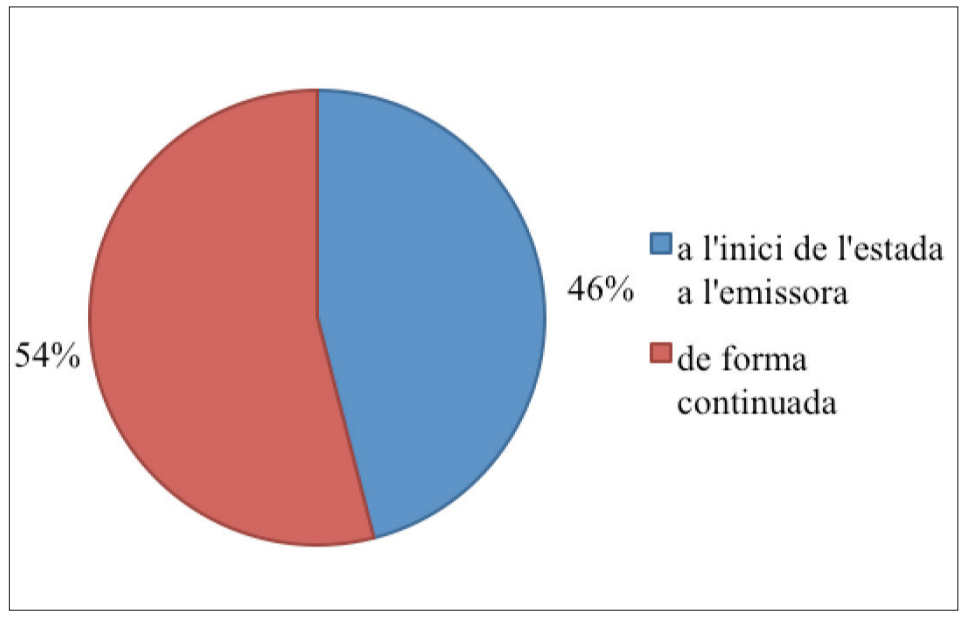

Font: elaboració pròpia

\section{Conclusions}

La realitat observada a la investigació està centrada en un aspecte del sistema mediàtic català poc explorat fins al moment, la figura dels col·laboradors dels mitjans de comunicació, en contraposició amb els professionals, i en un mitjà de comunicació concret com són les ràdios locals i comarcals. Si bé existeixen altres estudis dedicats a la polivalència professional als mitjans de proximitat de Catalunya, o a la seva situació laboral (Micó i Masip, 2010a; Scolari, Navarro Güere, Pardo Kuklinski i Micó, 2008), no hi ha recerques precedents que contraposin la condició laboral dels treballadors amb la dels col·laboradors.

A partir de la recerca s'han pogut definir les característiques de les professions lligades a les ràdios de proximitat catalanes, tals com el nombre i la formació de les persones que hi estan implicades, i el seu repartiment a les estructures de les ràdios.

Així, com a primera aportació destacada, es pot dir que a les ràdios locals catalanes no hi ha cap figura imprescindible, perquè cap de les feines ha de ser coberta necessàriament per un treballador o un col·laborador amb unes característiques definides de contracte i de formació. També cal tenir en compte que la intervenció de treballadors i col·laboradors a les ràdios no és simètrica, perquè hi ha voluntaris a totes les ràdios, però no a totes hi ha professionals.

El treball de camp ha posat de manifest que la definició del concepte de treballador, o professional, ja evoca una figura que té una vinculació laboral amb 
l'empresa, és a dir, a partir d'un contracte signat en què es delimiten les funcions que ha de portar a terme, la durada de la relació laboral i la remuneració econòmica que es rebrà per la feina feta. Per contra, la definició de la $\mathrm{col} \cdot$ laboració i el voluntariat es relaciona amb la contribució de la persona en el mitjà sense rebre una remuneració a canvi i per iniciativa pròpia sense que hi hagi la signatura d'una contracte laboral.

Prenent com a base la primera hipòtesi, s'ha vist que tots els treballadors de les ràdios locals i comarcals de Catalunya estan vinculats a les seves emissores a partir d'un contracte laboral signat amb l'empresa, que poden ser amb una empresa o fundació en el cas de les ràdios privades, o directament amb els ajuntament en les emissores públiques.

Si es para atenció als col·laboradors, s'ha de dir, d'entrada, que la seva participació a les ràdios està marcada pel voluntarisme, però que aquest voluntariat no és total: una quarta part d'aquestes persones, un $25 \%$, cobren per la seva col·laboració, i ho poden fer tant amb un ingrés al compte corrent com a través d'una associació externa que factura els diners a l'emissora de ràdio. En aquest sentit, els col·laboradors que perceben alguna remuneració són aquells que hi participen de forma més activa, pràcticament diària, però sense dedicar-hi una jornada laboral sencera.

Una de les aportacions més destacades de la recerca és que a les emissores de ràdios locals i comarcals catalanes hi ha més col·laboradors que treballadors. Numèricament, a les ràdios hi ha més voluntaris que professionals contractats, però de forma general al sector també hi ha més col·laboradors que treballadors perquè s'ha pogut observar que a totes les emissores hi ha persones que hi $\mathrm{col} \cdot$ laboren, però no a totes les ràdios hi ha professionals amb contracte.

Malgrat això, a les ràdios en què hi ha treballadors i col·laboradors, els primers són els que acostumen a ocupar els càrrecs de major responsabilitat, i la direcció és per a una persona remunerada.

Si es compara la presència de treballadors amb la de col-laboradors a les ràdios locals, el que s'observa és que el nombre dels primers és més baix que el dels segons. Són molt poques les ràdios que tenen més professionals que col·laboradors, de la mateixa manera que són pocs els casos d'emissores amb una xifra igual de presència de les dues figures. La proporció més elevada és la d'una major presència de col·laboradors que de treballadors, i hi ha emissores que funcionen només amb voluntaris. Per tant, la presència de col·laboradors es fa notar al conjunt de les ràdios locals catalanes.

El que s'ha vist amb la investigació és que el factor humà és el fet diferencial que serveix per explicar la realitat de les ràdios locals i comarcals catalanes, ja sigui per la relació entre les persones que hi participen o la proximitat entre emissors i receptors. Les persones que fan les ràdios són les que hi posen el segell identificatiu, i les que donen una riquesa al mitjà que va més enllà del procés periodístic de cercar informacions per transformar-les en notícies i explicar-les a l'audiència. 


\section{Bibliografia}

Bardoel, J. (1998). Converging Communications Policies. Developing a new policy framework. Paper presentat a la IAMCR-Conference, del 26 al 30 de juliol de 1998, Glasgow, Escòcia.

Benlloch Sanz, P. (2007). Panorama de las relaciones laborales en el tercer sector. A: Revista Española del Tercer Sector, $n^{0}$ 7. Madrid: Fundación Luis Vives, 131-163.

Busquet, J. (coord.); Medina, A.; Sort, J. (2006). La recerca en comunicació. Què hem de saber? Quins passos hem de seguir?. Barcelona: Editorial UOC.

Cantalapiedra, M. J.; Coca, C.; Bezunartea, O. (2000). La situación profesional y laboral de los periodistas vascos. A: Zer: Revista de estudios de comunicación, $\mathrm{n}^{\circ}$ 9. Bilbao: Universidad del País Vasco, 335-355.

Casares, F. (1991). Dret laboral i seguretat social: Règim jurídic del treball professional del periodista. A: Carrillo, M.; et al. Guia jurídica del periodista. Barcelona: Col·legi de Periodistes de Catalunya; J. M. Bosch.

Col· legi de Periodistes de Catalunya (2000). Estatut del periodista professional. Barcelona: Col·legi de Periodistes de Catalunya.

De Beer, A. S.; Merrill, J. (eds.) (2004). Global Journalism: Survey of International Communication. New York: Longman.

Domènech, J. Ll. (coord.) (2002). Diccionari bàsic de la Comunicació. València: Nau Llibres.

Doménech, H. (2011). El periodismo en la cultura digital. A: adComunica. Revista científica de estrategias, tendencias e innovación en comunicación, $\mathrm{n}^{\circ} 2$. Castelló: Universitat Jaume I, 233-235.

Deuze, M. (1999). Journalism and the Web: an analysis of skills and standards in an online environment. A: Gazette, $\mathrm{n}^{\circ} 61$ (5), 373-390.

Escobar Roca, G. (2002). Estatuto de los periodistas. Madrid: Tecnos.

Federació de Ràdios Locals de Catalunya (2011). Federació de Ràdios Locals de Catalunya. [Document electrònic]. Disponible a: <http://www.radiolocal.cat> [Consulta: 15 de març de 2011].

- (2008). Llibre blanc de la ràdio local pública. [Document electrònic]. Barcelona: Federació de ràdios locals de Catalunya. Disponible a: <http://www. radiolocal.cat/pub2/>. [Consulta: 9 de març de 2009].

García Avilés, J. A. (2007). Estándares profesionales en la convergencia de redacciones multimedia. Hacia una cultura periodística convergente. A: Masip, P.; Rom, J. (eds.). Les crü̈lles de la comunicació: límits i transgressions. Actes del IV Congrés Internacional Comunicació i Realitat. Barcelona: Trípodos, 2007. 
Lewis, P. M.; Booth, J. (1989). The Invisible Medium: Public, Commercial and Community Radio. Basingstoke: Macmillan.

López Vidales, N.; Ortiz Sobrino, M. Á. (2011). Perfiles profesionales en la radio española. Viejas nomenclaturas, nuevas competencias. A: Telos. Cuadernos de Comunicación e innovación, $n^{\circ}$ 87. Madrid: Fundación Telefónica, 1-10.

Martín Martín, F. (2004). Diccionario de Comunicación Corporativa e Institucional y Relaciones Públicas. Madrid: Editorial Fragua.

Masip, P.; Micó, J. Ll., et al. (2010b). Els reptes de la regulació en l'era de la convergència mediàtica. Barcelona: Consell de l'Audiovisual de Catalunya.

- (coords.) (2010a). La convergència comunicativa a la premsa local i comarcal. Noves perspectives per a la informació. Barcelona: Generalitat de Catalunya: Premsa Comarcal.

McKercher, C.; Mosco, V. (eds.) (2007). Knowledge workers in the information society. Lanham: Lexington Books.

Mosco, V. (2008) Knowledge Workers of the World! Unite?. A: Communication, Culture \& Critique, vol. $1, \mathrm{n}^{\mathrm{o}}$. 1. Washington: International Communication Association, 105-115.

Mosco, V.; McKercher, C; Huws, U. (eds.) (2010). Getting the message: communications workers and global value chains. London: Analytica Publications.

Observatori de la Ràdio a Catalunya (2011). Observatori de la Ràdio a Catalunya. [Document electrònic]. Disponible a: <http://www.l-obsradio.org> [Consulta: 15 de març de 2011].

Paulussen, S.; Heinonen, A.; Domingo, D.; Quandt, T. (2007) Doing It Together: Citizen Participation In The Professional News Making Process. A: Observatorio (OBS*) Journal, n ${ }^{\circ}$ 3, 131-154.

Pavlik, J. V.; Morgan, G.; Henderson, B. (2001). Information Technology: Implications for the Future of Journalism and Mass Communication Education. A: Journalism and Mass Communication Education: 2001 and Beyond, 16-20.

Petrus, A. (1991). Estudi comparat sobre voluntariat. Barcelona: Generalitat de Catalunya, Departament de Benestar Social.

Price-Davies, E.; Tacchi, J. (2001). Community Radio in a Global Context: A Comparative Analysis. Report for the Community Media Association (CMA). Sheffield: CMA.

Quivy, R.; Van Campenhoudt, L. (1997). Manual de recerca en ciències socials. Barcelona: Empresa editorial Herder. 
Real, E. (2006). Periodistas sin identidad profesional: puntualizaciones al proyecto para un futuro Estatuto. A: Ámbitos, $\mathrm{n}^{\circ}$ 15. Sevilla: Universidad de Sevilla, 333-361.

Scolari, C. A.; Navarro Güere, H.; Pardo Kuklinski, H.; Micó, J. Ll. (2008). Nous perfils professionals i polivalència del periodista a Catalunya. A: Quaderns del CAC, $\mathrm{n}^{0}$ 27. Barcelona: Consell de l'Audiovisual de Catalunya, 113-122.

Scholl, A. (1996). Sampling journalists. A: Communications, $n^{0} 21$ (3), 331-343.

Solà, S. (2012). Els treballadors i els col·laboradors de les emissores de ràdio locals i comarcals de Catalunya. Definició i funcions de les figures professionals. [tesi doctoral]. Barcelona: Universitat Ramon Llull.

Stevens, J. (2002). Backpack Journalism is Here to Stay. [Document electrònic]. A: Online Journalism Review, $\mathrm{n}^{\mathrm{o}}$ 2. Disponible a: <http://www.ojr.org/ojr/ workplace/1017771575.php>. [Consulta: 10 de desembre de 2011].

Taylor, S. J.; Bogdan, R. (1992). Introducción a los métodos cualitativos de investigación. La búsqueda de significados. Barcelona [etc.]: Paidós.

Tievant, S.; Chaguiboff, J. et al. (1986). Les radios de proximité: acteurs, produits, publics et vie locale. Paris: La Documentation française.

Tomás Frutos, J. (2009). Estudio, análisis e interpretación de la formación de los periodistas (El caso de Murcia) [tesi doctoral]. Murcia: Universidad de Murcia.

Wimmer, R. D.; Dominick, J. R. (1996). La investigación científica de los medios de comunicación. Una introducción a sus métodos. Barcelona: Bosch.

\section{Referencia d'aquest article}

Solà Saña, Sergi y Micó Sanz, Josep Lluís (2012). Presència i participació de treballadors i col-laboradors a les emissores de ràdio locals i comarcals de Catalunya. En: adComunica. Revista Científica de Estrategias, Tendencias e Innovación en Comunicación, $\mathrm{n}^{0} 4$. Castellón: Asociación para el Desarrollo de la Comunicación adComunica, Universidad Complutense de Madrid y Universitat Jaume I, 125-149. DOI: http://dx.doi.org/10.6035/2174-0992.2012.4.9 